Original Research Paper

\title{
Peningkatan Kemampuan Penulisan Sastra untuk Siswa SMA Negeri 1 Praya dalam Rangka Memajukan Literasi Sekolah
}

\author{
Nuriadi $^{{ }^{*}}$, Lalu Muhaimi ${ }^{1}$, Atri Dewi ${ }^{1}$ \\ ${ }^{1}$ Prodi Pendidikan Bahasa Inggris FKIP Universitas Mataram, Indonesia.
}

https://doi.org/10.29303/jpmpi.v3i2.1015

Sitasi: Nuriadi., Muhaimi, L., \& Dewi, A. (2021). Peningkatan Kemampuan Penulisan Sastra untuk Siswa SMA Negeri 1 Praya dalam Rangka Memajukan Literasi Sekolah. Jurnal Pengabdian Magister Pendidikan IPA, 4(4)

\author{
Article history \\ Received: 15 September 2021 \\ Revised: 20 September 2021 \\ Accepted: 27 September 2021 \\ *Corresponding Author: \\ Nuriadi, Prodi Pendidikan \\ Bahasa Inggris FKIP \\ Universitas Mataram, \\ Indonesia. Email: \\ nuriadi@unram.ac.id
}

\begin{abstract}
Makalah ini membahas kegiatan pengabdian (PKM) pada masyarakat yang dilangsungkan di SMA Negeri 1 Praya Kabupaten Lombok Tengah. Melalui kegiatan ini, antusiasme para peserta didik, siswa-siswa SMA Negeri 1 Praya, cukup tinggi. Dengan fakta ini, mereka juga terbangkitkan untuk menulis atau menghasilkan karya khsuusnya dalam bentuk puisi. Dengan demikian, kegiatan ini dianggap cukup berhasil dan mampu berkontribusi nyata di dalam memajukan literasi sekolah di bidang sastra bagi peserta didik di sekolah menengah. Sebagai implikasinya, kegiatan PKM dengan topik atau tajuk serupa seharusnya perlu dilakukan. Tidak hanya di sekolah itu saja, tetapi juga di sejumlah sekolah menengah lainnya yang mempunyai program literasi sekolah. Hadirnya kegiatan ini, peran Universitas Mataram semakin tampak dan dirasakan secara nyata bagi masyarakat umum.
\end{abstract}

Keywords: Pengabdian masyarakat, SMA Negeri 1 Praya, Siswa, Penulisan sastra, literasi sekolah.

\section{Pendahuluan}

Kegiatan pengabdian untuk masyarakat merupakan kegiatan wajib yang harus dilakukan oleh dosen atau pengajar di perguruan tinggi, selain kegiatan mengajar dan penelitian. Tiga kegiatan ini merupakan pilar perguruan dan jalur pokok hadirnya sebuah perguruan tinggi yang diamanatkan oleh Undang-Undang Pendidikan Tinggi yang kemudian diatur oleh peraturan pemerintah yang berada di bawahnya. Dengan hadirnya kegiatan pengabdian ini, peran perguruan tinggi benar-benar ada dan dirasakan secara langsung oleh masyarakat yang secara langsung ataupun tidak langsung berkaitan dengan visi-misi pendidikan yang dijalankan oleh perguruan tinggi. Oleh karena itu, Universitas Mataram, sebagai salah satu perguruan tinggi negeri terbesar di Nusa Tenggara Barat, senantiasa mendorong dan memprogramkan kegiatan pengabdian masyarakat
(PKM) untuk para pengajarnya tanpa kecuali., termasuk kami, yang menjadi pengajar di Program Studi Pendidikan Bahasa Inggris, Jurusan Bahasa dan Seni, FKIP, Universitas Mataram.

Kegiatan pengabdian yang kami jalankan dilakukan secara rutin di berbagai termpat selama ini. Dua berturut-turut pada tahun 2018 dan 2019, kegiatan PKM kami lakukan di Dusun Wisata Ende di Desa Sengkol, Kecamatan Pujut dengan proyeksi dan target yang hendak dicapai adalah meningkatan kemampuan bahasa dan pengetahuan budaya untuk para Pemandu Wisata Lokal yang bekerja sebagai pemandu menawarkan jasa informasi bagi para pengunjung manca Negara di tempat tersebut. Selanjutnya, pada tahun 2020, kegiatan pengabdian atau PKM kami laksanakan di SMA Negeri 1 Pujut dengan proyeksi meningkatkan kemampuan membaca dan mengapresiasi untuk para guru pengajar bahasa dan siswa-siswa jurusan bahasa di sekolah tersebut. Konkritna, tajuk yang kami 
angkat pada waktu itu adalah: "Pelatihan Kemampuan Mengapresiasi Sastra untuk Guru Bahasa dan Siswa-Siswa Jurusan Bahasa di SMA Negeri 1 Praya". Kegiatan ini diketuai oleh saya, Dr. H. Nuriadi S.S., M.Hum dengan anggotanya adalah: Dr. Muhammad Fadjri, Drs. Baharuddin, dan Muhammad Isnaini MA. Alhamdulillah kegiatan pengbdian tersebut berjalan cukup suskses dan berterima dengan baik oleh peserta yang hadir pada saat itu. Bahkan kegiatan ini membawa dampak positif terhadap sekolah tersebut.

Oleh karena itu, kegiatan pengabdian pada masyarakat untuk tahun 2021 ini dilangsukan kembali di SMA Negeri 1 Praya, dengan tajuk kegiatan adalah: Pelatihan Peningkatan Penulisan Karya Sasttra untuk Siswa-siswa SMA Negeri 1 Praya". Kegiatan ini diketuai oleh saya, Dr. H Nuriadi S.S., M.Hum, yang kali ini dianggotai oleh Dr. Lalu Muhaimi M.Pd. dan Atri Dewi, M.Hum. Kegiatan PKM tahun 2021 merupakan lanjutan dari kegiatan PKM tahun sebelumnya. Yaitu, kegiatan PKM tahun 2021 bermaksud untuk meningkatkan kemampuan penulisan karya sastra para siswa di SMA tersebut, termasuk para gurunya juga. Dengan kata lain, kegiatan PKM tahun 2021 merupakan upaya peningkatan kemampuan literasi siswa yang tidak hanya sekadar kritis dan akademis di dalam membaca serta mengapresiasi karya sastra (literasi estetis), tetapi juga mempu menciptakan atau memproduksi karya sastra dengan kemampuan fiksionalitas, pngatahuan dan rasa sastrawi yang baik (literasi artistik).

Dipilihnya SMA Negeri 1 Praya sebagai lokasi kegiatan PKM, bukan di sekolah menengah yang lain, adalah awalnya disebabkan karena faktor personal saja. Maksudnya, karena saya sebagai ketua kegiatan PKM merupakan alumni sekolah tersebut, yang sudah tentu masih mempunyai keterikatan emosional dengan sekolah itu selain masih mempunyai koneksi dan kontak dengan sejumlah guru yang mengajar di sekolah tersebut. Akan tetapi, menariknya, alas an personal ini menjadi tampak berubah ilmiah ketika ditinjau dari sisi peringkat dan keberadaan SMA Negeri 1 Praya di wilayah Kabupaten Lombok Tengah. SMA Negeri 1 Praya merupakan sekolah model dan sekolah menengah yang paling maju di antara sekolah-sekolah menengah yang ada di wilayah Lombok Tengah. Artinya, dengan hadirnya kegiatan PKM di tempat tersebut dan kegiatan PKM itu dianggap berhasil dan berdampak positif, hal ini kemudian akan memberi dampak yang bagus bagi sekolah-sekolah yang lain, yaitu: ia mampu memberi inspirasi untuk sekolah-sekolah yang lain. Hal ini dikarenakan sekolah model akan selalu dicontoh atau ditauladani oleh sekolah yang lain di walayah tersebut. Dengan demikian, maka keberadaan SMA Negeri 1 Praya akan semakin diakui dan Universitas Mataram, sebagai mitranya, pun akan mendapat apresiasi yang kurang lebih sama dari sekolah dan masyarakat.

Sehubungan dengan hal-hal di atas, makalah ini mncoba menyajikan deskripsi kegiatan PKM yang dilaksanakan akhir September 2021 di SMA Negeri 1 Praya dengan tajuk kegiatan yang disebut di atas yakni: Peningkatan Kemampuan Penulisan Karya Sastra untuk Siswa SMA Negeri 1 Praya dalam rangka memajukan literasi sekolah. Pembahasan makalah ini terbagi menajdi dua bagian, yaitu (a) deskripsi keberlangsungan kegiatan PKM dan (b) konten dan respon peserta PKM selama mengikuti kegiatan tersebut.

\section{Metode}

Makalah ini menggunakan metode deskriptif kualitatif. Metode ini mensyaratkan supaya sajian makalah dipresentasikan menggunakan kata-kata, narasi, deskripsi dan argumentasi, bukan dalam wujud sajian data yang berbentuk numeric ataupun statistik (Holliday, 2002). Selain itu, menurut Creswell (1998), dengan metode ini, sajian data seharusnya diambil dari data lapangan yang mencerminkan setting yang jelas dan jerni. Oleh karena itu, makalah ini berusaha menyajikan data dan laporan yang berseuaian dengan konsep dasar metode deskriptif dan kualitatif yang dimaksud di atas.

\section{Hasil dan Pembahasan}

\section{a. Proses Keberlangsungan Kegiatan Pengabdian Masyarakat}

Alhamdulillah, kata yang kami patut utarakan ketika mendapati respons sejumlah guru dan siswa yang mengikuti kegiatan pengabdian yang diselenggarakan. Dengan kata lain, kegiatan pengabdian dengan tema yang bersinambung dalam dua tahun berturut-turut di sekolah tersebut bisa 
dianggap cukup sukses. Indikator kesuksesannya itu minimal bisa dilihat dari antusiasme dan respons positif yang mereka tunjukkan ketika kegiatan pengabdian berlangsung ataupun setelah pengabdian selesai. Oleh karena itu, pengabdian ini kami pandang perlu dilangsungkan setiap tahunnya di beberapa tempat atau lokasi. Memang, kegiatan ini berlangsung faktanya juga didorong oleh permintaan langsung dari pihak SMA Negeri itu, khususnya dari Pembina Literasi Sekolah dan Kepala Perpustakaan SMAN 1 Praya, Ibu Nurmiana, M.Pd, Sebagai dampak positif dari kegiatan PKM di tahun sebelumnya, yaitu tahun 2020, meskipun dalam situasi pandemic Covid yang parah saat itu. Dan kebetulan memang, kegiatan PKM untuk model yang sama sudah diminta oleh sejumlah sekolah untuk tahun mendatang. Patut disyukuri memang.

Kegiatan PKM dilangsungkan pada hari Rabu tanggal 29 September 2021, siang hari. Kegiatan ini dilangsungkan dalam tiga sesi, yaitu sesi pembukaan atau sambutan, sesi penyuluhan atau pmeberian materi, dan sesi penulisan karya sastra, yang dalam hal ini bentuk karya sastra yang difokuskan adalah puisi.

Pada sesi pembukaan atau sambutan, pihak sekolah SMA Negeri 1 Praya memberi penyambutan yang cukup hangat kepada saya sebagai narasumber sekaligus pelaksana pengabdian di sekolah tersebut. Adalah pak Drs. H. Hapazah, M.Pd yang ditugasi kepala sekolah untuk menyambut saya pada acara tersebut. Beliau menyampaikan berbagai hal terkait dengan urgensi pelaksanaan kegiatan itu. Salah satunya, beliu mengatakan bahwa kemampuan menulis karya sastra merupakan kemampuan yang langka di samping menjadi wujud literasi tingkat tinggi dan HOTS bagi pengembangan diri peserta didik ke depan. Selain itu, beliau juga memberikan pengenalan-pengenalan kunci tentang saya sebagai pelaksana pengabdian di sekolah tersebut, karena memang beliau selama ini cukup intens mengikuti kegiatan saya di berbagai tempat termasuk sebagai pembaca aktif pada karya-karya sastra yang saya hasilkan.

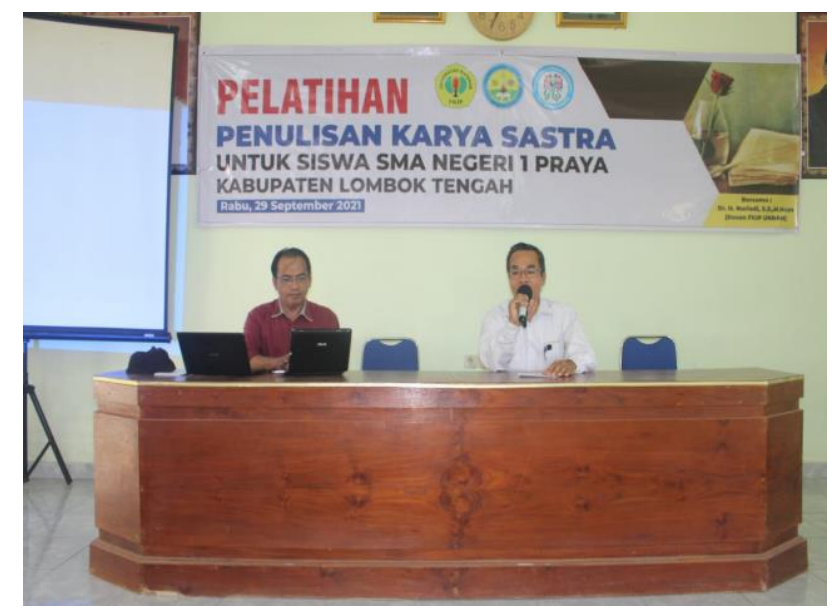

Foto 1. Foto Sesi Sambutan

Kemudian, pada sesi pemberian materi, saya sebagai pelaksana pengabdian berupaya memberi pemahaman tentang apa itu sastra, serta beberapa strategi yang harus dilakukan ketika hendak menulis atau menghasilkan karya sastra. Akan tetapi, lepas dari materi yang saya sampaikan, hal yang paling inti yang saya sampaikan kepada mereka adalah upaya pembangkitan motivasi mereka untuk terus giat belajar dan membaca selain membangun mimpi-mimpi mereka sebagai generasi penerus bangsa.

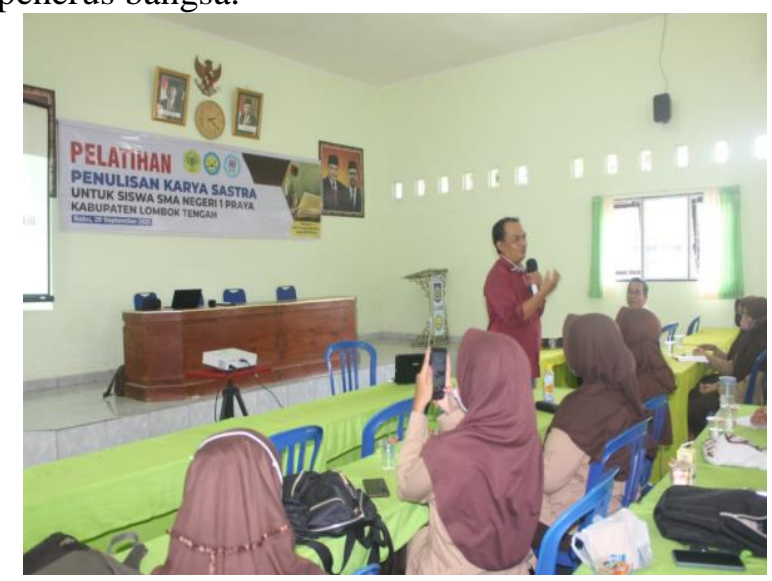

Foto 2. Pemberian Materi

Pada sesi terakhir adalah sesi penulisan karya puisi oleh para siswa-siswa, perserta kegiatan pengabdian masyarakat. Menariknya, semua peserta yang hadir di acara tersebut menulis puisi dengan sangat antusias tinggi. Mungkin hal ini disebabkan oleh introdusir yang saya lakukan sebelumnya. Tidak hanya menulis karya, mereka juga membacakan hasil karya puisi mereka di depan, dengan penuh penjiwaan serta untaian diksi yang cukup menarik. 


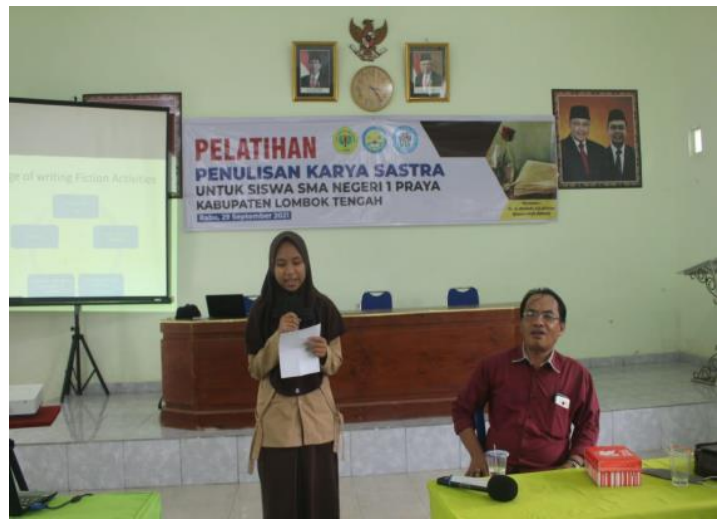

Foto 3. Pembacaan hasil karya Puisi

\section{b. Konten dan Respons Peserta Kegiatan PKM}

Sastra adalah bahasa kehidupan, bahkan kehidupan itu sendiri. Ia datang dari, oleh, dan untuk manusia dan kemanusiaannya (Nuriadi, 2016: 4). Hal ini disebabkan karena sastra muncul bertalitemali dalam bahasa verbal dan non-verbal manusia diwujudkan dengan ucapan dan perilaku manusia itu sendiri sebagai dokumen (artefak), wahana hiburan, dan bahkan sumber pencerahan kehidupan dan peradaban. Oleh karena itu terkait dengan keberadaannya di tengah kehidupan, tidaklah salah seorang penyair Amerika kenamaan, Robert Frost, berkata bahwa sastra adalah penampilan dalam kata-kata, 'performance in words' (Barnet, 1963: $1)$.

Istilah 'sastra', menurut Teeuw (via Ratna, 2007: 4), berasal dari bahasa Sanskerta, sementara istilah literature, sebagai padanan sastra dalam bahasa Inggris berasal dari bahasa Latin, litteratura. Kata 'sastra' berasal dari dua akar kata sas yang berarti mengarahkan, mengajar, memberi petunjuk, dan instruksi. Akhiran tra berarti alat, sarana. Jadi, secara leksikal sastra berarti kumpulan alat untuk mengajar, buku petunjuk atau buku pangajaran yang baik silpasastra (buku petunjuk arsitektur), kamasastra (buku petunjuk percintaan). Dalam perkembangan berikut kata sastra dikombinasikan dengan awalan 'su', sehingga menjadi susastra, yang diartikan sebagai hasil ciptaan yang baik dan indah. Dalam teori kontemporer sastra dikaitkan dengan ciri-ciri imajinasi dan kreativitas, yang selanjutnya merupakan satu-satunya ciri khas kesusastraan (Nuriadi, 2016: 8).
Karena ciri karya sastra yang berpangkal tolak pada imajinasi dan kreativitas (creatio) inilah, maka sastra atau kesusasteraan masuk atau digolongkan menjadi karya seni (a work of art), tidak lebih dari karya-karya lukisan, patung, serta wujud karya seni yang lain, kendatipun memang landasan penciptaannya tetap pada realitas-realitas manusia yang ada (imitatio). Akan tetapi yang membedakannya dengan karya seni yang lain adalah media ungkapnya saja, yaitu bahasa. Oleh karenanya sastra adalah karya seni imajinatif dan kreatif yang menggunakan bahasa (language) sebagai media ekspresinya. Pandangan ini tidaklah salah karena dalam proses penciptaan atau proses artistik sebuah karya sastra, seorang pengarang senantiasa melibatkan daya kreatif dan imajinatifnya sehingga hasil ciptaannya itu menjadi menarik, inspiratif, di samping bermakna dan bermanfaat bagi kemanusiaan manusia. Dalam tataran ini, sastra sejatinya terlingkupi oleh dua konsep yang disebutkan oleh Horatius, dulce dan utile (Siswanto, 2008: 87), yang berarti karya sastra harus bisa menghibur, menyenangkan, dan menimbulkan aspek estetis pada audiensnya (dulce) di samping itu memberi pembelajaran dan kemanfaatan bagi penikmatnya (utile) (Pradopo, 1995).

Kemudian, dalam konteks pembelajaran sastra, perlu diketahui bahwa penegajaran dan penulisan itu adalah sebuah keterampilan. Hal itu harus terus diasah dan di-upgrade sedemikian rupa, sehingga semangat dan penegtahuan para guru bisa ditingkatkan dengan cara berkala. Jika tidak demikian, maka tidak menutup kemungkinan terjadinya stagnasi dan kegiatan pengajaran bahasa, khususnya sastra, hanya berjalan apa adanya, tanpa adanya kreatifitas dan pengetahuan yang up to date. Sastra sebagai sebuah bagian dalam pembelajaran bahasa harus dimulai dengan hadirnya semangat dan contoh yang mengampunya. Dan karena itu, guru-guru bahasa harus selalu didorong dan disemangati sembari diberi pengetahuan baru tentang ilmu sastra dan aplikasinya. Topik sastra dipandang sebagai salah satu materi yang bersifat 'wajib ada' di dalam pengajaran dan atau pembelajaran bahasa di semua tingkatan pendidikan formal di Indonesia, khususnya di tingkatan sekolah menengah atas. Dia menjadi bagian inheren dalam akuisisi pembelajaran dan penguasaan bagi peserta 
didik ketika mereka mempelajari pendidikan bahasa di lembaga studi tersebut. Materi sastra ini bersandingan dengan penguasaan atau materi linguistik (ilmu bahasa). Asumsi dasar terhadap mengapa sastra menjadi bagian inheren dalam pembelajaran bahasa karena peserta didik diharapkan mampu mempraktikkan kemampuan berbahasanya tidak hanya dalam tataran aturan tata bahasa saja yang terkesan kaku dan matematis, tetapi juga menginternalisasi keterampilan berbahasanya itu dengan kecakapan intuisi, kepantasan, dan kesesuaian kontekstual (sosialbudaya) dengan pertimbangan sisi sastrawi. Adanya kecakapan berbahasa dalam konteks sastrawi seperti demikian menjadikan para pembelajar bahasa akan mampu berbahasa dengan tepat dan patut, tidak hanya baik dan benar dalam perspektif gramatikalnya saja.

Dalam praktik penulisan karya sastra, hal yang menjadi inti disampaikan pada kegiatan PKM di SMA Negeri 1 Praya itu adalah bahwa seorang penulis untuk bisa memulai menulis, dia harus bersikap open-minded terhadap apa saja yang menarik untuk diperhatikan, sikap open-minded ini akan mendorong dirinya untuk terus membaca. Membaca inilah kemudian menjadi inti awal dari semua proses kreatif berikutnya. Mengapa? Karena dengan banyak membaca, seseorang akan mempunyai pengetahuan dan wawasan yang banyak. Lalu, setelah itu, dia akan semakin kritis dan peka terhadap hal-hal yang ia anggap tidak berseuaian dengan kondisi normal dan kondisi seharusnya atas sebauah fenomena sosial dan alam di sekitarnya. Dengan modal Kekritisan dan Kepekaan itulah yang bisa mendorong mental dan bathin seorang penulis itu untuk menungakannya dalam bentuk tulisan. Inilah yang kemudian menjadi cikal bakal materi tulisan yang dikenal sebagai inspirasi. Inspirasi itu merupakan embrio yang mendasari munculnya materi dan ide cerita yang akan ditulis dalam sebuah karya sastra. Inspirasi itu kemudian mengkondisikan seseorang untuk menambahi dan mempertajam materi cerita sehingga akan semakin jelas ide dan amanat yang hendak disampaiak melalui cerita. Pun, inspirasi ini kemudian mendorongnya untuk berimajinasi di dalam mencari materi lainnya sehingga karyanya akan lebih terbaca dramatis dan menarik, jika itu dalam bentuk karya fiksi.
Respons konkrit dari materi yang disampaikan itu adalah para peserta cukup antusias. Yang mulanya tampak terlihat mengantuk dan kelelahan karena waktunya memang saat untuk pulang dan istirahat, tepai dipakai untuk kegiatan pengabdian. Menariknya, mereka tampak semangat. Mereka tidak lagi memgantuk. Mereka bahkan bersedia dengan penuh antusias menulis puisi yang secara spontan ditulis di tempat ini. Ada 45 peserta yang hadir, maka 45 buah karya puisi yang dihasilkan oleh mereka. Luar biasa memang. Sebagai bukti, berikut gambar atau foto karya puisi peserta PKM itu.

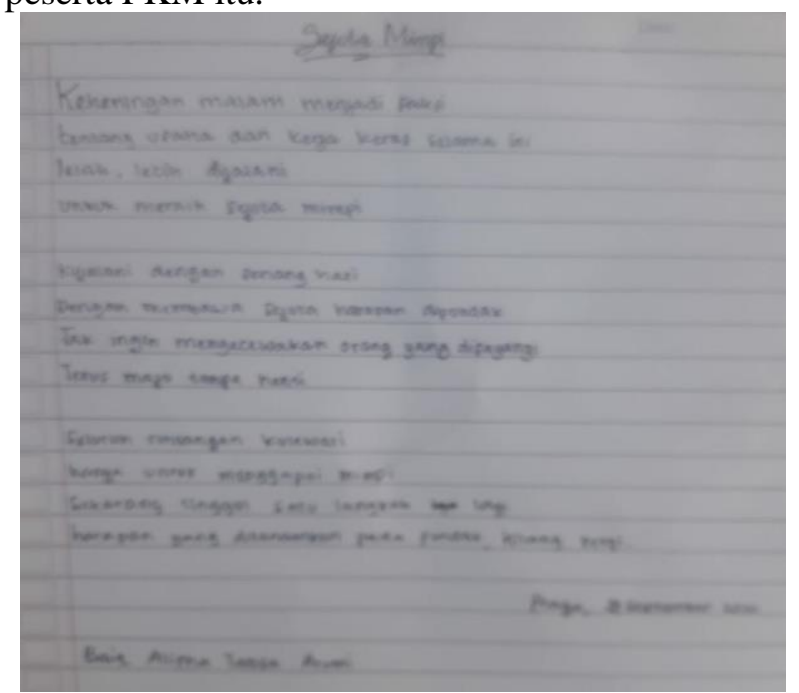

Foto 4. Karya Puisi Peserta PKM

Tidak hanya itu, para peserta, kurang lebih enam peserta, yang berani maju ke depan untuk membacakan hasil karya puisi mereka. Dengan kemampuan apresiasi dan interpretasi pada apa yng ditulisnya, mereka membacanya dengan penuh penjiwaan. Hal ini tentunya menjadi bukti nata bahwa bakat dan kemampuan mereka terhadap penulisan karya sastra memang sudah cukup bagus. Dan hadirnya kegiatan PKM dengan tajuk itu merupakan pemantik bagi mereka untuk terus berkegiatan dalam dunia tulis-menulis bidang sastra.

Akhirnya, kegiatan ini berakhir dengan ditutup secara resmi oleh Pak Guru Drs. H. Hapazah, M,Pd, lagi. Dengan penuh keceriaan, kegiatan ini diakhiri dengan foto bersama. Adapun bukti kegiatan aakhir acara tersebut tampak pada foto berikut. 


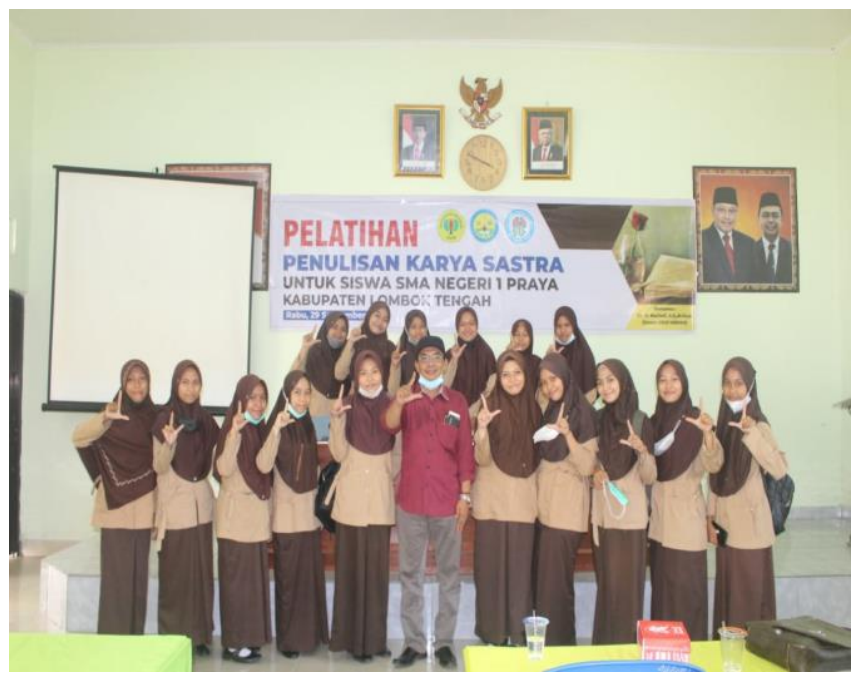

Foto 5. Bersama dengan Peserta PKM

\section{Kesimpulan}

Kegiatan PKM yang diselenggarakan oleh pihak Universitas Mataram akan selalu mendapat dampak positif apabila dilaksanakan dengan baik dan penuh tanggung jawab. Kegiatan PKM yang dilangsungkan di SMA Negeri 1 Praya pada tanggal 29 September 2021 merupakan bukti konkritnya. Dengan kegiatan ini, antusiasme para peserta didik, yang nota bene adalah siswa-siswa SMA Negeri 1 Praya, cukup tinggi. Dengan fakta ini, mereka juga terbangkitkan untuk menulis karya puisi. Mereka pun akhirnya menulis puisi pada saat itu juga. Dengan demikian, kegiatan ini dianggap cukup berhasil dan mampu berkontribusi di dalam memajukan literasi sekolah di bidang sastra bagi peserta didik di sekolah tersebut. Akhirnya, sebagai rekomendasi, kegiatan PKM dengan topic atau tajuk serupa seharusnya perlu dilakukan. Tidak hanya di sekolah itu saja, tetapi juga di sejumlah sekolah yang mempunyai program literasi sekolah. Dengan kegiatan ini, peran Universitas Mataram akan semakin tampak dan dirasakan nyata bagi masyarakat secara umum.

\section{Ucapan Terima Kasih}

Kami menghaturkan terima kasih yang tidak terhingga disampaikan kepada Bapak Rektor Unram dan Bapak Dekan FKIP atas perkenan ijin dan bantuan dana PNBP yang diberikan kepada kami. Ucapan terima kasih yang sebesar-besanrya juga disampaikan kepada Bapak Kepala Sekolah SMAN 1 Praya. Secara khusus, diucapkan terima kasih dan penghargaan yang besar kepada Ibu Nurmiana, M.Pd dan Bapak Drs. H. Hapazah M.Pd. atas bantuan dan sambutannya yang hangat.

\section{Daftar Pustaka}

Barnet, Sylvan et al. 1963. An Introduction to Literature: Fiction, Poetry, Drama. Second edition. Boston: Little, Brown and Company.

Creswell, John W. 1998. Qualitative Inquiry Research Design. London: SAGE Publications.

Nuriadi, Muhammad Fadjri, Baharudin, Muh. Isnaini. 2020. Peningkatan Kemampuan Mengapresiasi Sastra bagi Siswa Jurusan Bahasa di SMA Negeri 1 Praya. Laporan PKM LPPM Universitas Mataram.

Nuriadi. 2016. Theory of Literature: An Introduction. Mataram: Arga Puji Press.

Pradopo, Rachmat Djoko. 1995. Beberapa Teori Sastra, Metode Kritik, dan Penerapannya. Cetakan pertama. Yogyakarta: PT. Pustaka Pelajar.

Ratna, Nyoman Kutha. 2007. Sastra dan Cultural Studies: Representasi Fiksi dan Fakta. Cetakan kedua. Yogyakarta: PT. Pustaka Pelajar.

Siswanto, Wahyudi. 2008. Pengantar Teori Sastra. Jakarta: Penerbit PT Grasindo.

Djajati, S dan D. F. Rosida. 2015. Pengembangan Produk Olahan Mangrove dan Perikanan di Kawasan Pantai Wonorejo Surabaya. Prosiding Seminar Nasional "Sinergi Hasil Penelitian dan Pengabdian kepada Masyarakat untuk Menumbuhkan Kapasitas Inovasi di Bidang Teknologi, Pertanian, Sosial dan Ekonomi. Hal 381 - 387.

Efriyeldi,., A. Mulyadi , J. Samiaji1, Nursyirwani, Elizal dan E. Suanto. 2019. Peningkatan Nilai Ekonomi Ekosistem Mangrove Melalui Pengolahan Buah Api-Api (Avicennia sp) Sebagai Bahan Makanan Di Desa Sungai Kayu Ara Kabupaten Siak. 
Journal of Rural and Urban Community Empowerment, 1 (1) : 1 - 8.

Frazier RA, Deaville ER, Green RJ, Stringano E, Willoughby I, Plant J, and Mueller-Harvey I. 2010. Interaction of tea tannins and condensed tannins with proteins. J of Pharm and Biomedic Analysis 51:490-495.

Hagerman AE. 2002. Tannin Chemistry. Departement Chemistry and Biochemistry.Oxford (USA): Miami University.

Holliday, A. 2002. Doing and Writing Qualitative Research. Great Britain: The Cromwell Press Ltd.

Kardiman., M. Ridhwan dan Armi. 2017. Buah Lindur (Bruguera gymnorrhyza) sebagai Makanan Masyarakat Aceh Kepulauan. Jurnal Serambi Saintia, V (2) : 51 - 55.

Mayasari, R. 2015. Kajian Karakteristik Biskuit yang Mempengaruhi Perbandingan Tepung Ubi Jalar (Ipomea Batatas L.) dan Tepung Kacang Merah (Phaseolus Vulgaris L.). Skripsi. Universitas Pasudan. Bandung

Mohamad, I., I. Sudana dan Hasdiana. 2020. Pengembangan Seni Kerajinan Kerang Di Desa Modelomo Kecamatan Kabila Bone Kabupaten Bone Bolango. Laporan Akhir Program Pengabdian Kepada Masyarakat Fakultas Teknik Universitas Negeri Gorontalo. Gorontalo.

Mulyatun. 2018. Pemberdayaan Masyarakat Pesisir Berbasis Potensi Lokal; Alternatif Ketahanan Pangan Berupa Tepung Mangrove. Jurnal Dimas, 18 (2): $211-238$.

Proyono, A., D. Ilminingtyas, Mohsan, L. S. Yuliani dan T. L. Hakim. 2010. Beragam Produk OLahan Berbahan Dasar Mangrove. Kesemat. Semarang.

Rajis, Desmelati dan T. Leksono. 2017. Pemanfaatan Buah Mangrove Pedada (Sonneratia caseolaris) sebagai Pembuatan Sirup terhadap Penerimaan Konsumen. Jurnal Perikanan dan Kelautan, 22 (1): 5150.

Sahil, J dan I. Soamole. 2013. Pemanfaatan Buah Mangrove Sebagai Sumber Makanan
Alternatif di Halmahera Barat, Maluku Utara. Jurnal Biogenesis, 1 (2) : 91-96.

Setyaningsih D, Apriyantono A, Sari, MP. 2010. Analisa Sensori Industri Pangan dan Agro. IPB Press. Bogor.

Sitorus, A. K. 2019. Analisis Produk Olahan Buah Bruguiera Sexangula Menjadi Biskuit Dan Potensi Pasar Di Desa Sei Nagalawan Kecamatan Perbaungan Kabupaten Serdang Bedagai. Skripsi. Departemen Manajemen Hutan Fakultas Kehutanan Universitas Sumatera Utara Medan.

Sugianto. 2019. Diversifikasi Produk Olahan Mangrove Bisa Meningkatkan Kesejahteraan Masyarakat Pesisir Indramayu. Jurnal Mangifera Edu, 3 (2): 133-139.

Winarno, F.G. 1996. Kimia Pangan dan Gizi. Gramedia Pustaka Utama. Jakarta.

Wintah., A P. Heriyanti dan Kiswanto. 2018. Kajian Nilai Gizi Dan Organoleptik Cokelat Mangrove Dari Buah Sonneratia alba. Jurnal Litbang Kota Pekalongan, 15 : $26-34$. 